\title{
The Study of Quality of the River Pandayangan in His Review of the Factors of Physical-Chemical
}

\author{
Bunga Nasib Manalu', Arman Harahap ${ }^{2}$ \\ ${ }^{1,2}$ Faculty of Teacher Training and Education, Universitas Labuhanbatu, Indonesia \\ armanhrp82@yahoo.co.id
}

\begin{abstract}
The river is one of the forms of the aquatic ecosystem is open, which is also prone to the existence of a pollution.Pollution that occurs in a river is usually caused by environmental conditions and human activities around the river.The river water Pandayangan is one of the rivers that are widely used by the local community for a variety of activities, namely as a tourist attraction, bathing, washing, and others. This research is a descriptive research that aims to determine the water quality of the river in physics and chemistry of the location of the research based on the raw water quality. Research conducted at three locations and sampling the water for the third observation stations do the measurement of physical parameters such as Temperature, Color, and Turbidity while the chemical parameters include $p H, B O D$, Ammonia, Nitrite, Organic Number, Alkaliniti and Asiditi. Based on the results of testing the physical and chemical parameters then be concluded that the water quality of the river Pandayangan still meet the quality standards of water quality class $B$ or raw water.
\end{abstract}

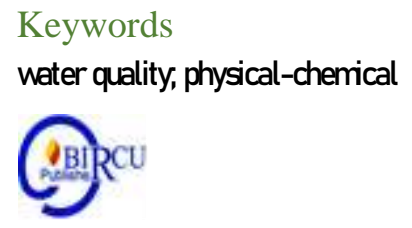

\section{Introduction}

The river is one of the aquatic ecosystems which have great benefits for sentient beings. The river is a source of surface water that provide benefits to human life.River Pandayangan is one of the tourist attraction that is popular in the District Silangkitang Kabupaten Labuhanbatu Selatan. The location of the river Pandayangan within 25 kilometers southwest of the city center Labuhanbatu Selatan. Around the river, there are several waterfalls that flow along the approximately 200 -meter section of the river. This makes the river is visited by many many people to enjoy the natural scenery around the river. This condition causes both quantity and quality will experience changes in accordance with the development environment of the river. The negative impacts that occur in rivers in the form of water pollution caused by human activity. Regular activity of man which is throw out the trash and dispose of industrial waste directly into the flow of the river can have an impact on aquatic organisms. In addition, the river many humans to take a shower and wash using soap and detergents contain chemicals. The chemicals in the soaps and detergents can also cause the deterioration of water quality (Merliyana, 2017). If the waste in the form of the contaminants get into a location the waters of the river can lead to change. Changes can occur in the aquatic environment itself in the form of factors of physics and chemistry and on the organism (biological) that live in that location (Suin, 1994). The impact of such pollution can be in the form of changes in community structure, decrease in biomass or productivity, changes in behavior, decrease in the rate of growth, disruption of the reproductive system, the loss of a kind - a rare type, change of durability over the life capability and others. The purpose of this study was to determine the water quality of the river Pandayangan in physics and chemistry. 


\section{Research Methods}

This research is qualitatif with the approach of descriptif. Research approach descriptif aims to explore the problems that there have been widely using existing theory, the opinion of experts regarding these aspects, penyelangan - penyelangan that have been done and results are walking or problems disarangan by the people - experts. (Surakhmed, 1980). The sampling technique is stratified cluster sample and sampling of water is carried out at three stations and this research was conducted in November-January. The coordinates of each station to the location of the research is the Station I : Latitude (152’38. $41^{\circ}$ "U) From Longitude (9957'13. 14’'T), Stasiun II : Latitude (1'52’37. 43 "U) From Longitude (99 $57^{\circ} 11.03$ 'T), Stasiun III: Latitude (1 $\left.{ }^{\circ} 52^{\prime} 33.30^{\prime \prime} U\right)$ From Longitude $\left(99^{\circ} 57^{\prime} 16.10\right.$ " T).

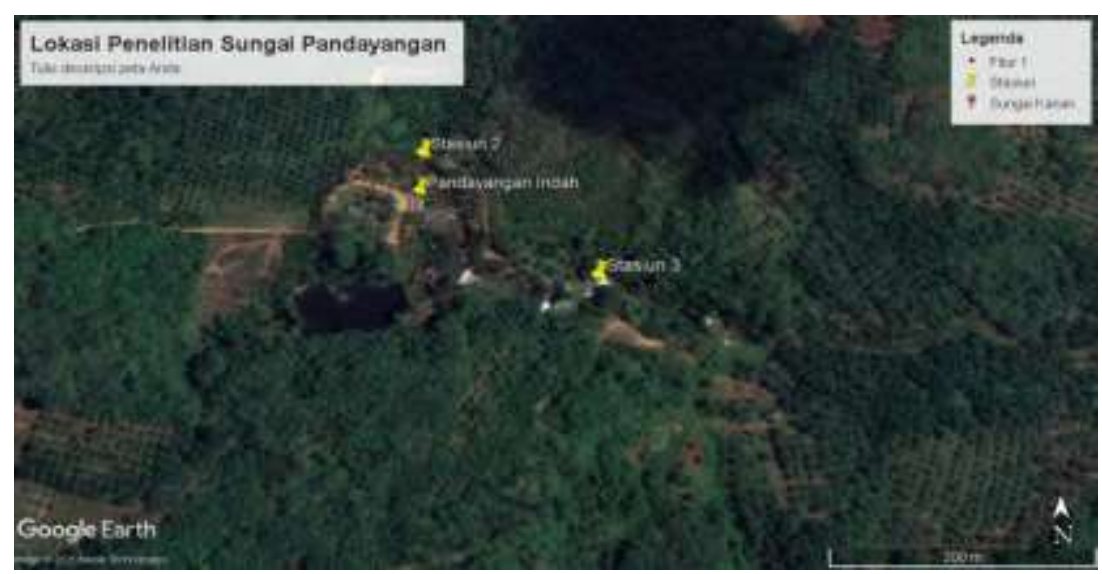

Figure 1. Location Research

The tools used in this research is a measuring cup, glass cup, kerta strain,labu ukur, labu Erlenmeyer, BOD Winkler, Pond Walkler, biur, pur, puretometer, pancuretometer, tabetometer, tabetometer. The materials used in the research is Alcohol.

\subsection{Working Procedure}

a. Temperature

1. Thermometer in the calibration with the thermometer bakudilakukan periodically.

2. Put the thermometer in such a way at the district location in order not direct contact with sunlight is usually covered with the shadow of the body, wait until the temperature scale on a thermometer showing the figure of a stable. Post air temperature at the scene.

3. Thermometer directly dipped into the water up to the limit of the scale and wait around 2-5 minutes until the figure shows a stable and posted the results obtained without lifting the thermometer from the water (the Department of PU, 1986). For testing the color is done using the methods of spectrophotometry, whereas the test turbidity using the methods nephelometri.

b. $\mathrm{pH}$

1. the $\mathrm{pH}$ meter was calibrated using buffer solution of $\mathrm{pH} 4$ and $\mathrm{pH} 7$. Rinse the electrode using a $\mathrm{pH}$ buffer and pat dry with a tissue. measuring the $\mathrm{pH}$ of the buffer solution and adjust the tool to the scale of the figure shows that in accordance with the $\mathrm{pH}$ of the buffer solution used. Do repetitions three times. 
2. Before used to measure the test sample, the first electrode rinse with distilled water three times and dried with a tissue.

3. Immerse the electrode into the test sample is \pm 1 minutes and then dry with a tissue.

4. Replace the instance of the test and immerse the electrode into the test sample until the $\mathrm{pH}$ meter shows a reading which is fixed.

c. Ammonia Test

1. Measure $200 \mathrm{ml}$ of test sample, put it in a pumpkin distiller $500 \mathrm{ml}$.

2. Add $12.5 \mathrm{ml}$ buffer solution of boric acid as well as a few grains of stone boiling.

3. Tepatkan $\mathrm{pH}$ to 9.5 with the addition of a solution of $\mathrm{NaOH} 5$ using a $\mathrm{pH}$ meter.

4. Turn the tool refiners and adjust the speed of the distillation of $5-10 \mathrm{ml} / \mathrm{min}$.

5. Capacity of the distilled water in the Erlenmeyer flask $250 \mathrm{ml}$ that has been in the contents of $15 \mathrm{ml}$ of boric acid solution and the capacity of the distilled water to $100 \mathrm{ml}$ or does not contain ammonia which can be determined by litmus.

6. Dilute to $250 \mathrm{ml}$ with the addition of distilled water.

7. The test sample is ready for testing.

8. Read the absorbance using a spectrophotometer and calculate the levels of ammonium by using the calibration curve. If the levels of Ammonium $>5 \mathrm{mg} / \mathrm{L}$, repeat testing by diluting the test sample.

\section{d. Nitrite Test}

Methods : Brusin Sulfate

1. Optimize spectrophotometer according to the instructions to use the tool.

2. Pipette $25 \mathrm{ml}$ of each standard solution nitrite and the example of water, then insert it into the Erlenmeyer flask.

3. Add $0.5 \mathrm{ml}$ of a solution of sulfanilic acid.

4. Allow the solution to react for 2-8 minutes.

5. Add $1 \mathrm{ml}$ of solution solution naphthyl etilendiamin dihydrochloride, stir and let stand at least 10 minutes, but not more than 2 hours.

6. Measuring uptake of the entry using a spectrophotometer with a wavelength of $543 \mathrm{~nm}$. Calculate the levels of nitrite based on the calibration curve.

7. If nitrite levels $>0.5 \mathrm{mg} / \mathrm{L}$ repeat testing by diluting the test sample.

Testing BOD is done by using a tool DOmeter, to test the Organic Substance Amount (figure permanganate) using the method of permanganometri. If the use of a solution of raw potassium permanganate $>7 \mathrm{ml}$, repeat testing by diluting the test sample. As for the test Aciditas (Acidity) and Alkalinity (Alkalinity) using a potentiometric method. 


\section{Results and Discussion}

Based on the results of examination of the physical parameters and chemical parameters of the three locations of research, the data obtained summary of which can be seen in the following table:

Table 1. The results of the examination of the water of the river Pandayangan in physics and chemistry

\begin{tabular}{|c|c|c|c|c|}
\hline No. & Parameter & Station I & Station II & Station III \\
\hline \multirow[t]{4}{*}{1.} & Physics & & & \\
\hline & a. Temperature & $27,4^{\circ} \mathrm{C}$ & $27,6^{\circ} \mathrm{C}$ & $28,5^{\circ} \mathrm{C}$ \\
\hline & b. Color & 5,1 scale $\mathrm{PtCo}$ & 4,9 scale $\mathrm{PtCo}$ & 4,2 scale $\mathrm{PtCo}$ \\
\hline & c. Turbidity & 9,17 scale $\mathrm{TU}$ & 12,7 scale $\mathrm{TU}$ & 14,1 scale $\mathrm{TU}$ \\
\hline \multirow[t]{8}{*}{2.} & Chemistry & & & \\
\hline & a. $\mathrm{pH}$ & 7,8 & 7,5 & 7,3 \\
\hline & b. BOD & $3,3 \mathrm{ppm}$ & $2,8 \mathrm{ppm}$ & $3,9 \mathrm{ppm}$ \\
\hline & c. Ammoniac & $0,2 \mathrm{ppm}$ & $0,4 \mathrm{ppm}$ & $0,1 \mathrm{ppm}$ \\
\hline & d. Nitrite & $0,03 \mathrm{ppm}$ & $0,05 \mathrm{ppm}$ & $0,05 \mathrm{ppm}$ \\
\hline & e. Numbers of $\mathrm{KMnO}_{4}$ & $9,2 \mathrm{ppm}$ & $8,3 \mathrm{ppm}$ & $9,6 \mathrm{ppm}$ \\
\hline & f. Acidity & $6,1 \mathrm{ppm}$ & $7,5 \mathrm{ppm}$ & $8,2 \mathrm{ppm}$ \\
\hline & g. Alkalinity & $130 \mathrm{ppm}$ & $125 \mathrm{ppm}$ & $145 \mathrm{ppm}$ \\
\hline
\end{tabular}

\subsection{Physical Parameters}

The measurement results of samples obtained air temperature at three locations, namely Station I and Station II is a $29.2{ }^{\circ} \mathrm{C}$ and at Station III is of $30.4{ }^{\circ} \mathrm{C}$, if the comparison of the results of measurements of water temperature obtained for the Station I : $27,4{ }^{\circ} \mathrm{C}$, Station II : OF $27.6^{\circ} \mathrm{C}$ and Station III: OF $28.5^{\circ} \mathrm{C}$. The temperature measurement is very important because it affects the solubility of substances in water so that it will have no effect on the value of $\mathrm{pH}, \mathrm{DO}$ and so on. Based on the results of the temperature measurement, the value still meet the provisions of the water quality standard class B according to PP. No. 20 Th. 1990 on water pollution control and the provisions of the maximum limit of clean water according to PERMENKES RI.416/MENKES/PER/IX/1990. The measurement results of samples obtained by the Station I : 5,1 ; Station II : 4.9 and Station III: the 4.2-scale PtCo. The color of the water is usually caused by organic substances derived from plants or from the ground, the degree of acidity or $\mathrm{pH}$ of the very large influence on the color of water.The difference in the value of the color obtained is likely caused by the presence of organic substances in the number of different or the state of the geology of the river flow and the color value of the sample is still under the provisions of the maximum limit of clean water according to PERMENKES. RI. 416/MENKES/PER/IX/1990, which is 50 scale PtCo, but the value of color should not be contained in the criteria for water class B according to PP. No. 20 Th. 1990 on water pollution control.

If seen from the results of testing a sample of the value of the turbidity for sample Station I : 9,17 ; Station II : 12,7 and Station III: 14,1 scale NTU. Turbidity is caused by particles of clay and some minerals, particle size ranged from 0.2 to $0.5 \mathrm{u}$, which when left some long will precipitate. The value is still under the provisions of the maximum limit of clean water according to PERMENKES.RI 416/MENKES/PER/IX/1990 25 scale NTU.The value of the turbidity should not be contained in the criteria for water class B according to PP. No. 20 Th. 1990 on water pollution control. 


\subsection{Chemical Parameters}

Based on the results of testing each sample obtained by the $\mathrm{pH}$ value of the Station I : 7,8 ; Station II : 7.5 and Station III: a 7.3. The $\mathrm{pH}$ value is greater than the 9.2 or smaller than 6.5 can cause corrosion in the pipes of the water and cause some chemical compounds turn into toxins that interfere with the health and value - the value is still in the range of $\mathrm{pH}$ value on the quality of the raw water quality class B according to PP. No. 20 Th. 1990 on the control of pollution of water, namely of 5.0 - 9.0 and in terms of the maximum limit of clean water according to PERMENKES. RI 416/MENKES/PER/IX/1990 i.e. 6.5 to 9.0.

The results of measurements on samples obtained value of the BOD that Station I : 3,3 ; Station II : 2.8 and Station III: the $3.9 \mathrm{mg} / \mathrm{L}$. The value of BOD is an indication of the biological basis of the presence of pollution of organic substances that occur in the waters, the magnitude of the value of this parameter is influenced by the level of pollution that occurred, but the value of the BOD should not be there in criteria air of class B according to PP. No. 20 Th. 1990 on water pollution control and the provisions of the maximum limit of clean water according to PERMENKES RI. 416/MENKES/PER/IX/1990 (Anonymous, 1990).

The results of testing the sample value of ammonium to sample at Station I : 0,2 ; Station II : 0.4 and Station III: $0.1 \mathrm{mg} / \mathrm{L}$. The presence of ammonium compounds can lead to the emergence of smell is very sharp and piercing the nose so that it affects the aesthetics of the value is still under the provisions of the raw water quality group B of 0.5 $\mathrm{mg} / \mathrm{L}$ according to the PP. No. 20 Th. 1990 but the value of ammonium should not be there in terms of the maximum limit of clean water according to PERMENKES. RI 416/MENKES/PER/IX/1990 (Trangna N, 1993).

The value of nitrite obtained from measurements on a sample of Station I : 0,03 ; Station II : 0.05 and Station III: $0.05 \mathrm{ppm}$. the existence of the compound of nitrite in water can cause "Methahemoglobine" that hinder the passage of oxygen in the body. The value obtained is still below the maximum extent permitted according to the quality of the raw water quality class B according to PP. No. 20 Th. 1990 and conditions limit the maximum clean water according to PERMENKES. RI 416/MENKES/PER/IX/1990 is 1.0 $\mathrm{mg} / \mathrm{L}$.

The value of the Observations for a sample of Station I : 9,2 ; Station II : 8,3 and Station III: $9.6 \mathrm{mg} / \mathrm{L}$. The value of the permanganate is the presence of organic substances in a body of water and the value of $\mathrm{KMnO} 4>10 \mathrm{mg} / \mathrm{L}$ can cause odors that are unpleasant and cause abdominal pain and the value of the sample is still within the limits of clean water according to PERMENKES. RI 416/MENKES/PER/IX/1990 but the value of the permanganate should not be there on the criteria of the water group B (PP. No. 20 Th. 1990 on water pollution control (Trangna N, 1993).

The results of the examination of the value of the sample Station I : 6,1 ; Station II : 7.5 and Station III: $8,2 \mathrm{mg} / \mathrm{L}$. Asiditas can also cause corrosion to the pipes of the water and the higher the value asiditas sample then the corrosion on the pipes of the water will be faster to happen, but the value of asiditas should not be there in criteria air of class B according to PP. No. 20 Th. 1990 and conditions limit the maximum clean water according to PERMENKES. RI 416/MENKES/PER/IX/1990 (Trangna N, 1993).

The results of the examination of the value of alkalinity to the sample Station I : 130; Station II : 125 and Station III: $145 \mathrm{mg} / \mathrm{L}$. As is the case asiditas, alkalinity can also cause corrosion to the pipes of the water, but the value of the alkalinity should not be there in criteria air of class B according to PP. No. 20 Th. 1990 or the provisions of the maximum limit of clean water according to PERMENKES. RI. 416/MENKES/PER/IX/1990. 


\section{Conclusion}

Based on the results of testing parameters in physics and chemistry obtained, then a conclusion can be drawn the water of the river Pandayangan still meet the provisions of the raw water quality class B or raw water quality according to the PP. No. 20 Th. 1990 on water pollution control and PERMENKES. RI 416/MENKES/PER/IX/1990.

\section{References}

Anonim, 1986 .Jilid II Pedoman Pemeriksaan Kualitas Air. Balitbang Pengairan Departemen Pekerjaan Umum.

Anonim, 1990.SNI Bidang Pekerjaan Umum mengenai Kualitas Air, Edisi akhir.Departemen Pekerjaan Umum Jakarta.

Anonim , 1990. Petunjuk Pemeriksaan Air Minum/Air Bersih. Departemen Kesehatan Pusat Laboratorium Kesehatan Jakarta.

Anonim, 2014. Laporan Biro Pusat Statistik Mataram Tahun 2014

Anonim, 1990.Peraturan Menteri Kesehatan RI. No. 416 Tahun 1990, Tentang Kualitas dan Persyaratan Air.

Anonim, 1990. Peraturan Pemerintah No. 20 Tahun1990, Tentang Pengendalian Pencemaran Air.

Alaerts dan Santika, 1987.Metode Penelitian Air. Usaha Nasional : Surabaya.

Merliyana, 2017. Analisis Status Pencemaran Air Sungai dengan Makrobentos sebagai Bioindikator di aliran Sungai Sumur Putri Teluk Betung, Skripsi . Lampung: Fakultas Tarbiyah dan Keguruan UIN Raden Intan.

Surakhmad W, 1980. Pengantar Penelitian Ilmiah (dasar, metode dan teknik) Edisi - 7. Tarsito Bandung : Bandung.

Trangna N, 1993. Aspek Kualitas Air dalam Pemanfaatan Sumber - sumber Air.Putlitbang Pengairan : Bandung. 